Illinois State University

ISU ReD: Research and eData

Theses and Dissertations

$4-5-2021$

\title{
Bewitching The Blame: The Crucible'S Legacy Of Appropriation And Sexual Shame In Popular Culture
}

Hope Kristine Morris

Illinois State University, hopekmorris@gmail.com

Follow this and additional works at: https://ir.library.illinoisstate.edu/etd

Part of the Theatre and Performance Studies Commons

\section{Recommended Citation}

Morris, Hope Kristine, "Bewitching The Blame: The Crucible'S Legacy Of Appropriation And Sexual Shame In Popular Culture" (2021). Theses and Dissertations. 1395.

https://ir.library.illinoisstate.edu/etd/1395

This Thesis is brought to you for free and open access by ISU ReD: Research and eData. It has been accepted for inclusion in Theses and Dissertations by an authorized administrator of ISU ReD: Research and eData. For more information, please contact ISUReD@ilstu.edu. 


\section{BEWITCHING THE BLAME: THE CRUCIBLE'S LEGACY \\ OF APPROPRIATION AND SEXUAL SHAME \\ IN POPULAR CULTURE}

\section{HOPE MORRIS}

61 Pages

In The Crucible Arthur Miller uses tropes of female characters, Abigail and Tituba, to tell a story of male heroism. In the process, he dismisses and appropriates the true stories of women who suffered during the Salem witch trials for his own political and personal gain. In this thesis, I argue that Miller's appropriation and sexualization of women continues into contemporary popular culture depictions of the Salem witch trials including the movie adaptation of The Crucible and the television shows Salem and American Horror Story: Coven. These depictions appropriate and sexualize women's stories in order to fulfill the male gaze. This thesis also explores how three contemporary women playwrights are writing new plays that address the sexism of Arthur Miller, show how The Crucible perpetuates abuse, and encourage women to confront sexism by creating their own works about the Salem trials. These plays are Abigail by Sarah Tuft, John Proctor is the Villain by Kimberly Belflower, and Becky Nurse of Salem by Sarah Ruhl. Finally, I argue that in order to have a true feminist redemption of the Salem witch trials in popular culture, there must be more creative and scholarly analysis of Tituba, a woman of color who has been most silenced in these depictions.

KEYWORDS: Abigail Williams, Arthur Miller, male gaze, Salem Witch Trials, The Crucible, Tituba 
BEWITCHING THE BLAME: THE CRUCIBLE'S LEGACY OF

APPROPRIATION AND SEXUAL SHAME

IN POPULAR CULTURE

HOPE MORRIS

A Thesis Submitted in Partial

Fulfillment of the Requirements

for the Degree of

MASTER OF SCIENCE

School of Theatre and Dance

ILLINOIS STATE UNIVERSITY

2021 
(C) 2021 Hope Morris 
BEWITCHING THE BLAME: THE CRUCIBLE'S LEGACY OF

APPROPRIATION AND SEXUAL SHAME

IN POPULAR CULTURE

HOPE MORRIS

COMMITTEE MEMBERS:

Ann Haugo, Chair

Kee-Yoon Nahm

Kyle Ciani 


\section{ACKNOWLEDGMENTS}

Thank you to Dr. Ann Haugo, Dr. Kee-Yoon Nahm, and Dr. Kyle Ciani for their continued feedback and support. Thank you to Cheyenne Flores, Breeze Pollard, Hannah Sellmyer, Col Connelly, Ari Garcia, Kristi Morris, and anyone else who I have swindled into reading chapters and offering feedback. Thank you to Sarah Ruhl for allowing me to read and analyze Becky Nurse of Salem. Thank you to Molly Briggs-Yonke and Kelsey Fisher-Waits for helping me find the plays, Abigail and John Proctor is the Villain. Thank you to Aaron Manke who created the podcast, Unobscured, which first inspired my interest in the Salem witch trials. Thank you to everyone else who listened to me cry over this project, who listened to be ramble about the "a-ha!" moments, and who told me not to give up when I really thought I might.

H.M. 


\section{CONTENTS}

Page

ACKNOWLEDGMENTS $\quad$ i

$\begin{array}{ll}\text { CONTENTS } & \text { ii }\end{array}$

$\begin{array}{ll}\text { INTRODUCTION } & 1\end{array}$

CHAPTER I: MILLER'S MISREPRESENTATIONS OF THE WOMEN OF THE 10

TRIALS

CHAPTER II: BLAMING FEMALE SEXUALITY AND BLACK MAGIC 25

Blaming Female Sexuality $\quad 25$

Blaming Black Magic $\quad 34$

CHAPTER III: A FEMINIST RESPONSE $\quad 40$

$\begin{array}{ll}\text { CONCLUSION } & 55\end{array}$

WORKS CITED 59 


\section{INTRODUCTION}

In colonial America, at least thirty-three people were executed for witchcraft. Twentyfive of these people died during the infamous witch trials of Salem, Massachusetts. To summarize the trials as explained by Salem scholar Mary Beth Norton in her book In the Devil's Snare and Stacy Schiff in her book The Witches: Salem, 1692, in the cold winter of early 1692, the household of Reverend Parris of Salem village was disturbed by the strange behavior of his nine-year-old daughter, Betty, and his eleven-year-old niece, Abigail Williams. Another child, Ann Putnam, began to behave the same way. The girls appeared to be bewitched as they barked like dogs, flung themselves across rooms, and had seizure-like fits. Betty, Abigail, and Ann named their bewitchers: Tituba, an enslaved Indigenous woman of the Parris household, and two impoverished local women, Sarah Good and Sarah Osbourne. In response to the accusation, Tituba spun an elaborate confession where she spoke of the devil's great force that caused her to bewitch the children. After some painful persuasion, she began to name other cohorts of the devil. Soon many women and girls (and some men) of Salem caught on and began to accuse their neighbors, enemies, and even their own families. Schiff explains the panic in these words: "The youngest of the witches was five, the eldest nearly eighty. A daughter accused her mother, who in turn accused her mother, who accused a neighbor and minister. A wife and daughter denounced their husband and father. Husbands implicated wives; nephews their aunts; sons-inlaw their mothers-in-law; siblings each other. Only fathers and sons weathered the crisis unscathed" (4).

There is speculation over what truly caused this witch craze. Was it the desire for property? Was it economic greed? Was it an attempt to rid Salem of its less desirable citizens? Scholars have dedicated entire books in an attempt to explain the hysteria of the trials. Schiff 
presents a list of many common theories: "generational, sexual, economic, ecclesiastical, and class tensions; regional hostilities imported from England; food poisoning; a hothouse religion in a cold climate; teenage hysteria; fraud, taxes, conspiracy; political instability; trauma induced by Indian attacks; and to witchcraft itself, among the most reasonable theories" (4-5). Regardless of intention, Salem's afflicted community members accused men, women, and children, both old and young of the devil's work, leading to the execution of many.

This tragedy not only devastated an entire community; the massacre of supposed witches (mostly women) contributed to the dominance of a religious patriarchy in early American law. Women could not read, practice medicine, run businesses, own land, be midwives, marry again, or even be poor without being accused of being under the devil's influence. The social systems supported by the Puritanical accusations towards women still have effects today, as Kristin J. Sollee explains in her book Witches, Sluts, Feminists: Conjuring the Sex Positive. She quotes the Sabbat Cycle mission statement, saying, "Nearly four hundred years after the first execution of the American 'witch,' many in our nation still call for the establishment of an American theocracy and a return to the puritanical delusions of old (47)." The witch trials were a grave tragedy primarily against women, and the theocratic oppression that they established continues to affect the way women's autonomy is revoked in contemporary America specifically through anti-abortion legislation, lack of representation in government, and refusal to believe women. The witch trials deserve to be and need to be remembered and represented. However, in popular culture today, many representations of the Salem witch trials are tempered through a misogynistic lens that perpetuates abuse of women.

The most influential representation of the Salem witch trials in the 20th century is Arthur Miller's play The Crucible which was written and first performed in 1953 during the Red 
Scare in the United States. The play begins with Reverend Parris stumbling upon a group of young girls, including his daughter and niece, dancing in the woods (Miller 10). To protect herself, his niece, Abigail, accuses Tituba of bewitching them, crying, "She made me do it! She made Betty do it...She makes me drink blood!" (43). Tituba, in fear of her life, confesses to witchcraft: "No, no, don't hang Tituba! I tell him I don't desire to work for him, sir" (44). Soon Tituba and the young girls in the town begin to name witches. Abigail, who is "seventeen...a strikingly beautiful girl...with an endless capacity for dissembling" in Miller's play, lusts after John Proctor, her previous employer (8-9). When he rejects her out of loyalty to his wife, Abigail names Goody Proctor in the courtroom as a witch. In an attempt to save his wife through confession of his sexual sins, John Proctor himself is convicted of witcheraft and hanged.

This play creates fictional relationships in a historical setting. Yet The Crucible presents itself as a factual account of the events of Salem by using real names and details of the Salem witch trials. However, Miller's interpretation strays far from the truth in many crucial ways. Miller admits in "A Note on the Historical Accuracy of this Play," that the play is not entirely factual. He says, "This play is not history in the sense in which the word is used by the academic historian" (Miller 2). To him, history is found in the essence of the story as he perceives it, as I will discuss further in chapter one. This is because he is appropriating the story for his own political agenda.

According to the book Communists, Cowboys, and Queers by David Savran, Miller wrote The Crucible as an allegorical comparison of the Salem witch trials and the era of McCarthyism in the mid-twentieth century. Savran calls the play Miller's "heroic indictment of McCarthyism" (21). The Crucible aims to criticize Miller's the harsh practices of the 1950s US government, and while the play achieves his purpose of a political narrative, Miller sacrifices the 
narratives of the truly oppressed women of Salem. Real women and girls who lived and died in the midst of this tragedy are forgotten, demonized, and objectified to achieve Miller's personal agenda of political resistance. In the process, two female characters are highly misrepresented: Abigail Williams, the accuser, and Tituba, the accused. While the inaccuracies of the portrayal are useful for creating a compelling plot, the misogynistic and xenophobic lens they create has affected the way the trials are perceived today. My intent in this paper is not to criticize Miller's lack of historical accuracy, but to argue that the changes he made have significant effects on the way sexuality and otherness are perceived surrounding the trials. There are a variety of other influential plays and movies in American culture that represent the trials, however, I have chosen to center my research on The Crucible for not only its widespread popular appeal but for its role in the English and theatre classrooms as educational material. Many important figures in the trials are misrepresented in The Crucible, and many are entirely left out. To examine the individual history of each of these figures is an admirable goal, but the limitations of this project have led me to focus on two of the characters who have the most existing scholarship surrounding their roles in The Crucible: Abigail Williams and Tituba Indian.

The Crucible, the most popular cultural depiction of the Salem witch trials, does not appropriately address the patriarchal impact on the women involved as both accusers and accused. The Crucible centers the story around a male protagonist and both sexualizes and villainizes the persecuted women and girls of Salem's society. Feminist scholars have previously analyzed the plays in favor of Miller's interpretation of the female characters. In the book, Feminist Rereadings of Modern American Drama, June Schlueter argues that Miller's representation of Abigail Williams empowers her politically and sexually. Schlueter claims that "by challenging the apparently decent men and women of Salem, the young women, led by 
knowing Abigail, act to scourge hypocrisy, punish its practitioners, and exact revenge for their socially determined impotence" (123). She understands Abigail's character as one of agency and power. However, I argue that Miller's depiction of Abigail revokes the power of truthful representation. True empowerment comes from redeeming the female truth of the oppressive trials. By putting Abigail in a position of power, Miller places the blame of the trials on corrupt female sexuality. More feminist scholarship surrounding The Crucible is needed to address the misrepresentation of the real women in Miller's play. In the third chapter of my thesis, I will explore three feminist plays that are doing just this.

The New England witch trials of the late seventeenth century contributed to women's role as the victim of a patriarchal society. According to Sollee in her book, Witches, Sluts, Feminists: Conjuring the Sex Positive, as the feminist movement has grown in history, specifically in the 1960s, the history of the witch trials has been reclaimed and used as a symbol to address the contemporary persecution of women based on economic independence and sexual shame. She says, "By the feminist explosion of the 1960s, the time was ripe for the witch to be revived and regaled as a political symbol" (Sollee 52). Sollee explains that witchcraft has been reclaimed by women throughout the U.S. as a way to get in touch with the feminine power that was stripped from them in the making of American society. She expands, "Many view the witch as the embodiment of a powerful femininity rooted in the earth, which transcends patriarchal influence" (Sollee 19). This growing interest in what I will term, witch feminism, continues to redeem the narrative of the Salem witch trials. However, interpretations of the women of Salem as sexual deviants and barbarous foreigners still overwhelm the popular culture surrounding the trials as I will explore in the second chapter of this thesis. To accurately embrace the ancestry of the witchy woman in American society, the true stories of suffering and manipulation endured by 
the women of Salem must be understood and represented, especially in modern media. Feminist artists should continue to create new works that represent these women.

This understanding is difficult to come by in the current education surrounding the Salem witch trials. Sollee says, “Ask anyone educated in America about Salem, and they’re likely to come up with a salacious tidbit about that eventful year," but after a survey of a diverse group of Americans, she concludes that "though everyone was familiar with the brouhaha, misinformation abounded" (33). Much of the education concerning the trials takes places in the literature class while reading The Crucible. The Crucible is a staple in American theatre thus it is widely read by young people in English and theatre classes. While the play offers a pathway to literary analysis, it creates misconceptions about the real historic events. The play accomplishes Miller's purpose of scorning McCarthyism during the Red Scare, but also creates fictional precedents for real events in American history, specifically events that still impact women today. The Salem witch trials added to an already boiling colonial hatred of women's economic and sexual freedoms. The effects of this hatred and the massacre that came with it have carried a legacy of shame into present society that impacts women and lingers in popular culture.

This form of patriarchal shame and hatred is not unique to North America, however. The history of witch trials in Western culture is both endlessly fascinating and horrific. According to Witch Craze: A New History of the European Witch Hunts by Anne Barstow, it is estimated that there are over 50,000 recorded executions during the age of the witch hunt in Europe, much more than in North America (22). Salem's witch hunt seems small in comparison. While there are many compelling examples of misrepresentation concerning the European witch trials, to write about them all would take a much larger thesis. For this reason and for its direct impact on American culture, which I understand more familiarly, I focus my research on the 
trials within the New England colonies in the seventeenth century, more specifically, the Salem trials of 1692 .

Representations of Salem are still popping up in film, plays, literature, and television shows. Many contain storylines, characters, and themes from Arthur Miller's play. The specific examples I will be addressing in chapter two are the 1996 film version of The Crucible with Daniel Day Lewis and Winona Ryder and the television shows Salem and American Horror Story: Coven. In the 1996 movie, Abigail Williams is turned into a manipulative and sexual being that creates the conflict of Salem to quench her sensual desires. Likewise, Tituba becomes a voodoo witch woman who provokes the children into demonology. In the television show Salem, a woman's greed and sexuality (though not Abigail Williams) is centered as the cause of the witch scare. Additionally, the character of Tituba becomes the guilty party by forcefully bewitching the main character and making her a powerful companion of the devil. Finally, the anthology television show, American Horror Story: Coven, claims that there are two sects of witches: the descendants of Salem and the descendants of Tituba. The two parties are at war with one another and the most powerful descendants of Tituba, all Black, perform terrifying and harmful voodoo on their Salem counterpart, all white. In each of these adaptations, Arthur Miller's depictions of Abigail and Tituba are used to perpetuate inaccurate tropes and further misrepresent the real women of Salem in a misogynistic and xenophobic light. These tropes appeal to the male gaze and reveal the continued male appropriation of women's stories.

Using Sollee's concepts of feminism, I will point out cultural misrepresentations of these characters and conjecture the reasons for them. I will use the feminist lens to examine how the witch trials contributed to a dominant patriarchal American culture, and how accounts with women as the sexual villains perpetuate this oppressive culture. Along with this, I will use an 
intersectional approach to analyze Tituba's role as an "other" who takes the blame for the trials as a Black woman yet wields none of the power of witchcraft. The primary purpose of these analyses is to examine The Crucible's effect on the perception of female sexuality and "foreign" cultural practices and to emphasize the modern importance of accurately retelling the lives of the oppressed women of Salem, both the accuser and the accused. In my final chapter, I will introduce three newly written plays, Abigail by Sarah Tuft, John Proctor is the Villain by Kimberly Belflower, and Becky Nurse of Salem by Sarah Ruhl, that respond to Miller's work by calling out his misogyny and appropriation, recognizing the abuse The Crucible perpetuates, and creating a redemptive frame for the women of Salem and today.

There is plenty of discourse about The Crucible, but most analysis focuses on the male protagonist, John Proctor. For example, in Communists, Cowboys, and Queers, the male author focuses exclusively on the analysis of masculinity in Miller's play. Abigail's lust is considered an attack on this masculine power. The majority of scholarly discussion about the play puts little value in recovering the reputation of the female characters that Miller distorts, but rather focuses on Abigail Williams and Tituba as fictional catalysts for the play's events. The play turns two victimized women into tropes: the vengeful mistress and the voodoo practicing enslaved African woman. The blame of the tragic witch trials becomes associated with female sexuality and foreign culture. My search for scholarship about Abigail and Tituba has led me to sources addressing the historical inaccuracies including Victoria Pope's article for the U.S. News and World Report, "Myth v. Reality." However, most of the sources, including video materials made for educational purposes, interpret the two women as the instigators of the trials rather than victims of oppressive circumstances. The sources that have crafted my understanding of the trials themselves are The Witches by Stacy Schiff, the history channel documentary, Salem Witch 
Trials, the podcast Unobscured by Aaron Manke, In the Devil's Snare by Mary Beth Norton, Devil in the Shape of a Woman by Carol F. Karlsen, and Records of Salem witchcraft, copied from original documents. These sources each offer a unique perspective on the comprehensive history of the Salem trials.

The Crucible offers insight into Puritanism as well as McCarthyism. However, in the process of creating these perspectives, Miller disparages the true oppression suffered by the women of Salem and appropriates it for his own political and personal gain. The trials become a man's game, where women are the villains, and the stories of many key female players in the trials are forgotten or misremembered. Abigail Williams and Tituba Indian are two of these women whose truths have been skewed and sacrificed in order to achieve Miller's narrative and agenda. These tropes affect popular culture's depictions of Salem still today. In becoming aware of current popular culture misunderstandings and redeeming the truth of these women, modern feminists can better understand the circumstances that solidified the patriarchal structure of America's society from a young age and create new works that elevate the silenced stories. 


\section{CHAPTER I: MILLER'S MISREPRESENTATIONS OF THE WOMEN OF THE TRIALS}

Arthur Miller's play The Crucible has become one of the foremost works of literature about the Salem witch trials. It is often used in educational settings to discuss Puritanism and is widely produced onstage in its original setting. The play was not written primarily as an educational source about the trials, however. The play was intended to allegorically address the harsh practices of McCarthyism during the Red Scare of Miller's time. In this chapter, I will examine how Miller appropriates history to accomplish his own personal and political goals. I will specifically address the way women are treated in his story through examination of the characters of Abigail and Tituba. I will illuminate how Miller's demonization and sexualization of these women functions as his plot device, his fulfillment of the male gaze, and his personal valorization.

This appropriation of women's stories paints Miller as the overcomer and hero of the Red Scare. In Communists, Cowboys, and Queers, David Savran explains Miller's leftist role in the "witch-hunt" against communism and calls The Crucible "his [Miller's] heroic indictment of McCarthyism, in 1953" (20-21). Miller, who was accused of being a communist during the Red Scare, places himself as the tortured hero of the Red Scare through the allegory of John Proctor on trial. Though The Crucible is arguably one of the greatest American plays--Miller is certainly regarded as one of the greatest American playwrights--and does accomplish its goal of speaking to Miller's contemporary issues, the true history and real lives involved in one of early America's painful atrocities are objectified in achieving this. This begs the question: when does allegory become appropriation? Appropriation is defined by the Cambridge Dictionary in two ways, both of which I believe apply here, "the act of taking something for your own use, usually 
without permission" and "the act of taking something such as an idea, custom, or style from a group or culture that you are not a member of and using it yourself" (Cambridge Dictionary), Alternatively, an allegory is defined as "a story, play, poem, picture, or other work in which the characters and events represent particular qualities or ideas that relate to morals, religion, or politics" (Cambridge Dictionary). While the events in The Crucible do represent the political ideas of Miller, they are events and ideas taken from real people and their trauma. These real people, particularly the women affected by the trials, are used as Miller's pawns for political commentary rather than studied and respected as a crucial part of history. Beyond this, Miller takes many liberties to make the Salem Witch Trials fit into his allegorical framework.

While Miller never claims that The Crucible is completely factual, he does make a few major claims to justify his decision to rewrite Salem's story. First, he claims that the information needed to make the play completely accurate does not exist: "As for the characters of the persons, little is known about most of them" (Miller 2). This note makes the assertion that thorough records do not exist--or at least not enough to assist in telling the story. However, records have existed since the trials about what occurred, including detailed transcripts of the court proceedings, diary entries of the prominent men in Salem, and letters written by the women and accused. Many authors have used those to craft the story of Salem. Acknowledging the existence of some sources, Miller reassures readers that he is as accurate as possible and uses his imagination to fill in the gaps, saying, "I believe that the reader will discover here the essential nature of one of the strangest and most awful chapters in human history. The fate of each character is exactly that of his historical model, and there is no one in the drama who did not play a similar--and in some cases exactly the same--role in history" (2). Miller justifies warping the facts by asserting that his play captures the essence of the truth, which is more real than 
verifiable evidence. In Making of Salem: The Witch Trials in History, Fiction, and Tourism, Robin DeRosa discusses this authorial power. She states, "For although this play is fiction, it (and not "real history") contains the 'essential nature of what happened.' In other words, Miller tries both to offer a disclaimer about the imaginative aspects of his work, and to claim a higher level of veracity for the play's authority" (DeRosa 133). Miller grants himself authority to reshape history by raising the importance of "dramatic purposes" (Miller 2). However, it is important to acknowledge that access to these historical sources may have been limited when Miller was writing the play, and the sources specifically written by women may have not been deemed significant or worthy of study at the time.

While the changes Miller made may be acceptable to apply to the male characters in the play, I argue they greatly misrepresent the women. Miller starts his notes with helpful factual evidence about Salem and its inhabitants to aid the reader. The notes seem to be his way of differentiating fact and fiction in the play. He writes that his play is truthful "except as indicated in the commentary I have written for this text" (Miller 2). He gives evidence such as: "At the time of these events Parris was in his middle forties" and other very basic facts (Miller 3). However, this transforms when he begins his descriptions of Abigail Williams and John Proctor. No longer are the notes factual materials to read along with the play; instead, they are his personal opinions and choices about the characters. He says of John Proctor, "the steady manner he displays does not spring from an untroubled soul. He is a sinner" (Miller 20). Before he begins to assert his opinions, Miller has made himself a reliable source through his notes. Because of this, his change to fictional creation is so subtle that it is easy to mistake it for truth. Though Miller has not claimed to be entirely factual, he has set a precedent for truth. When he breaks this precedent, he forces the reader into a false view of Abigail, one that identifies her as a 
sexual temptress and of Tituba, one that claims she is equipped with exotic powers. While it may seem innocent enough to change a few historical details to create a work of fiction, the effects of Miller's depiction of the Salem witch trials have been lasting. Because of his presentation of the details, popular culture has continued to adopt the notion that the trials began because of Abigail and Tituba.

To any Salem scholar or student, the most obvious factual slip of Miller's play centers around Abigail Williams, the niece of Salem's reverend and one of the first afflicted persons in Salem. In Miller's play, Abigail Williams is introduced as a seventeen-year-old woman and described as "a strikingly beautiful girl, an orphan, with an endless capacity for dissembling" (Miller 9). All sources from the trials indicate that Abigail Williams was actually eleven years old, hardly more than a child, though she likely carried many adult responsibilities even at the early age of eleven (Schiff ix). It is possible that Miller conflated Abigail with another accuser, seventeen-year-old Mercy Lewis, who was orphaned during Wabanaki attacks in the King Philip's War (Norton 49). Like Abigail, Mercy also was one of the key accusers of Elizabeth Proctor during the trials. However, in The Crucible, Mercy herself is portrayed as a character in the play as one of the accusers. Regardless of his reasoning, the age difference of Abigail, as well as the sultry description, immediately calls into question Miller's driving point to the plot of The Crucible, the affair between Abigail Williams and John Proctor.

Sources indicate that John Proctor was in his sixties at the time of the trials (Schiff xii). In Miller's text John Proctor is explicitly described as a "farmer in his middle thirties...powerful of body, even-tempered, and not easily led...In Proctor's presence a fool felt his foolishness instantly" (Miller 20). Not only has the age been changed to justify the affair, but the description also inserts Miller's personal characterization of Proctor that has no historical proof backing it. 
In the article "The Crucible of History," William J. McGill Jr. argues that the affair is a possibility. He says, "it is not implausible that an Abigail, even if only eleven, could develop a romantic fixation on her employer. Furthermore, the likelihood that such a fixation might have issued in a sexual relationship cannot be dismissed" (McGill 260). Yet even McGill acknowledges that the change of Proctor's age from sixty to thirty implicates a likelihood that history does not. McGill's argument shows that The Crucible's legacy of misogyny has lived on in scholarly criticism. Though the suspicion of Abigail and John Proctor's affair is baseless, McGill holds Miller's words as a possibility where a young girl could have tempted a man into sexual deviance.

Regardless, drawing a conclusion from these age differences, as well lack of historical record, the affair between John Proctor and Abigail Williams most likely never happened. In her book, The Devil in the Shape of a Woman, Carol F. Karlsen argues that Miller began this sexual implication through The Crucible. She says, "the idea that the possessed were sexually “promiscuous...stems in part from the popularity of Arthur Miller's The Crucible....Miller changed the age of Abigail Williams, from 11 to 17 and made sexual motives the basis of her accusations" (Karlsen 344). While Abigail did accuse John Proctor and Goody Proctor of being witches, her allegations probably had more to do with her uncle's resentment of the Proctors than with her sexual agenda or grudge. John Proctor, like many other prominent citizens in Salem, did not support Parris's ministry and believed him to be greedy and selfish. He refused to pay him in firewood and denied his request to own the parsonage personally. Parris was likely resentful of this and could very well have used his niece to exact revenge. Despite this knowledge, Miller's depiction of Abigail as a sex-hungry temptress with a "confidential, wicked air" and "endless capacity for dissembling" places the blame for a major tragedy on her shoulders--which, in 
reality, are the shoulders of an eleven-year-old orphan (Miller 342, 333).

In the article "Scapegoating Non-Conforming Identities: Witchcraft Hysteria in Arthur Miller's The Crucible and Caryl Churchill's Vinegar Tom," Tarih Kültür and Sanat Araştırmaları Dergisi explain that Abigail "is described as the ultimate femme fatale with tempting physical appearance" and "is denied a chance to explain her real motives behind her actions by the author" (7). The femme fatale was a popular trope by the time Miller wrote the play. In an article written for The Week by Scott Meslow, he argues that the first depiction of the femme fatale is "Eve, the first woman, who ended up snaring a hapless guy named Adam...but the basic, archetypal narrative of a woman tempting a man into his own downfall turns out to be a culturally pervasive one... like Circe and Clytemnestra...like succubi and yuki-onna...like Cleopatra, Lucrezia Borgia, and Mata Hari." He goes on to explain that this iconic woman who uses "her unapologetic sexuality as a kind of blunt cudgel against the male protagonist" gained popular traction through Noir films of the early 20th century (Meslow). This misogynistic trope has often been regarded as a thrilling plot device, which could easily indicate Miller's decision to depict Abigail in such a way. In some of his other works, like After the Fall, he depicts women as these whorish characters. By portraying Abigail as a seductive villainess, Miller appeals to an audience's desire to "have it both ways, enjoying the vicarious, prurient sexuality while knowing she'll eventually be punished for it" (Meslow). This theory leads me to argue that Miller adapted Abigail's character to create a crowd-pleasing plot and character trope. Unfortunately, this decision disregards and disenfranchises the real women of Salem's history. Likewise, it exploits and demonizes female sexuality as the cause of the fall of not only Salem but of Miller's political climate as well.

Another major tweak to reality made by Miller is found in his depiction of Tituba, the 
woman enslaved by Salem's reverend (Abigail's uncle) and the first person to be accused of and confess to witchcraft. According to Arthur Miller's story, Reverend Samuel Parris "brought her with him from Barbados" (8). Tituba's descendancy is in reality widely debated. In original transcripts of the trials, she is referred to as a "Tituba Indian," "the Indyen woman," "titibe an Indian Woman," suggesting that she was from a tribe indigenous to America (Norton 21). The majority evidence supports this idea that she is of "Amerindian descent," and Mary Beth Norton argues in her book, In the Devil's Snare, that "Tituba came from Florida or the Georgia Sea Islands...almost certainly not born in New England...thus not of Wabanaki origin" (21). Though Tituba was an Indigenous woman, she was likely Arawak, not of a tribe that citizens of Salem were familiar with in their area. Despite many scholars arguing that she is likely of Arawak descent, Tituba is almost always portrayed as a Black Caribbean or African woman in documentaries, television shows, books, and even museums. Tituba was likely captured from the Americas and brought to work on a plantation in Barbados. Because the number of enslaved Amerindian people in Barbados was relatively small, it is possible for scholars to trace the personal history of Tituba. Records trace the sale of a young enslaved Indian girl named "Tattuba" to distant relations of Samuel Parris (Breslaw 22). Though there are no records directly stating that this is the same woman, the rare nature of the name has led scholars to assume it is the same Tituba. What is known for certain is that Parris, after a failed mercantile career in Barbados, moved to Boston taking Tituba with him as his servant. After their arrival, we know only the basics of Tituba's life--she was married to another servant of the Parris household, John Indian. It is supposed by some scholars that she also had a daughter named Violet, but there are no formal records of this.

I was surprised in my research to see how often the media claiming to be historically 
accurate depicted Tituba as Black. This depiction of Tituba as a Black woman has become common due to Arthur Miller's changes in The Crucible. In the article, "The Metamorphosis of Tituba, or Why American Intellectuals Can't Tell an Indian Witch from a Negro" by Chadwick Hansen, he argues that "the last vestige of Tituba's actual race withered away Arthur Miller's play, The Crucible, leaving her a "slave." And in Miller Tituba's magic is blacker as well as her race" (10). Norton says, "Every surviving piece of contemporary evidence identifies her as an Indian. Later tradition transformed her into an African or half-African slave" (20). According to Hansen's statement, it is Miller who effectively erases her true identity. This change in ethnicity may on the surface seem insignificant, but in light of the play, it makes her the prime target to receive the blame of the trials. Tituba is considered an outsider, someone from a foreign land bringing her culture's dark magic with her. Unlike the "civilized" white protestants, Tituba, portrayed as a Black woman, is expected to know magic and voodoo. In the introduction to her book, Tituba, Reluctant Witch of Salem, Elaine Breslaw states, “There is no reference anywhere in the seventeenth-century documents to Tituba as an African or as someone of an African background. Like the mythology of Tituba as a voodoo priestess, there is no indication in the extant records that either Tituba or her husband had African ancestry" (xxi). Why did Miller choose to depict Tituba as a Black woman rather than Indigenous? Breslaw argues that this change began before Miller stating, "The gradual metamorphosis of Tituba from an Indian to an African since the nineteenth century is an unfortunate mistake based on embellishment, imagination, and a tinge of racial bias" (xxi). I suggest that it is more than a tinge. I conjecture that Miller's perpetuation these myths to appeal to preconceived notions of Blackness and witchcraft.

One effect of Miller's depiction of Tituba as Black is to appeal to the familiarity of the 
popular perception of enslaved Black women in his time period. A well-known depiction of an Black enslaved woman that has permeated American culture is the "mammy" figure--an offensive imagining of the Black nursemaid in the Old South who dotes upon her master's children. This iconic character can be found anywhere from dishware to film, and even museums. A perplexing reality is that even the Salem Witch Museum in today's Salem, MA has a wax figure portraying Tituba as Black and in stereotypical mammy garb. In her article, "Reproducing Witchcraft: Thou Shalt Not Perform a Witch to Live," V.K. Preston describes this effigy, "The wax museum's staging of Tituba, presenting the most notorious character of the Salem trials, is a particularly overt example of linking contemporary discourse on race and labor through scenes of alleged witchcraft. The aproned and corseted Tituba effigy at the wax museum...evokes a mammy figure in racist 19th- and 20th-century iconography" (149). In portraying Tituba as a mammy figure, Miller turns her into a more "palatable" character and refuses to recognize her uniquely oppressive situation. He describes her love for Betty: "she...can no longer bear to be barred from the sight of her beloved" (Miller 32). By embracing the sentimentalized and inaccurate depiction of enslaved women as beloved by their owners, Miller ignores the traumas suffered by them and erases the many Indigenous women who were enslaved in the colonial era.

However, I argue that the most resounding effect of Miller's change of her race is to add further mystery and intrigue to his play by exoticizing the witchcraft. How could such terrible witchcraft come to a town of the Puritan elite? It is much simpler to blame the devilry on an outside source, particularly from a world already associated with dark magic. By making Tituba a Black Carribean woman, he implies an association with voodoo that places the blame of Salem's mysteries on her shoulders. Breslaw explains, "Interest in Tituba and her role in the 
1692 events has traditionally focused on her supposed witchcraft molded by the practice of voodoo...derived from African folklore" (xx). Why would Miller want to evoke these images? The terror that rose in Salem in the year of 1692 has puzzled scholars for centuries. There are countless theories including "class tensions; regional hostilities...food poisoning...cold climate; teenage hysteria; fraud, taxes, conspiracy; political instability; trauma induced by Indian attacks; and...witchcraft itself' (Schiff 4-5). Rather than leave the truth of the trials open ended, Miller selects an easy target to shoulder the blame--the foreign enslaved woman who lived in the Parris household at the time of the girls' strange affliction.

In The Crucible, Abigail and the other girls seek out Tituba, whose "foreign" origin associates her with witchcraft, to conjure spirits and predict their fortunes. Miller here adds another false element to his play, though it is not seen onstage. It becomes clear within the first act of the play that Abigail, Betty, and the other young girls of the village went with Tituba to dance and conjure spirits. Parris accuses Abigail, saying, "I saw Tituba waving her arms over the fire when I came on you...And I heard a screeching and gibberish coming from her mouth. She were swaying like a dumb beast over that fire...And I thought I saw--someone naked running through the trees!" (Miller 11). It is even implied that Tituba made Abigail a potion to kill Goody Proctor. A bewitched Betty wakes to scream at her cousin, "You drank a charm to kill John Proctor's wife! You drank a charm to kill Goody Proctor!” (Miller 19). There is no evidence to support this massive change to the plot and charge against the female characters. By adding this scene, Tituba and the girls of Salem do not remain afflicted of great illness and hysteria as we see them in history. Rather, they become the cause for their own affliction by bringing dark magic into the society. In this we see most clearly that Miller manipulates history for his own agenda that places primary blame on the women of Salem instead of its oppressive patriarchal 
figures.

If in The Crucible Abigail's lust is the spark of the trials, the confession of Tituba is the flame. After being accused of afflicting the children of her household, Tituba confesses to witchcraft. Her elaborate confession includes graphic details of the devil and his cohorts who force her to hurt the little girls. It is Tituba's testimony that secures the dismal fate of Sarah Good and Sarah Osborne. Her accusations empower the young girls to take their claims further and cause the judges to begin the largest witch hunt in American history. While Tituba's confession truly happened and truly fueled the witch trials, there are important details of her story which have been distorted in popular culture, in large part due to the legacy of The Crucible.

Scholars have puzzled for centuries as to why Tituba not only confessed to witchcraft but also spun a wild tale that incriminated nine other Salem villagers. Some argue it was to take ownership of a situation where there was no winning, to exact her revenge on the town while avoiding execution through confession. Breslaw argues, "Quite likely she also hoped that confessing to supernatural power would intimidate her tormentors into leaving her alone...Invoking the Devil...was one of those extra-legal weapons used by powerless people who would challenge law and authority. Tituba devised an even more imaginative use of that kind of resistance to protect her life" (116-117). Tituba's confession truly was a moment where, for perhaps the first time in Salem, the power was in an enslaved woman's hands.

Despite this confession, perhaps the most important of Miller's distortions to address is Tituba's own dalliance in witchcraft. What we know of Tituba is that she was a God-fearing woman who prayed alongside Reverend Parris and his family. In Puritan culture, Parris would have held a responsibility to manage the morals of his slaves as well as family. Breslaw explains, 
"Samuel Parris...had religious obligations to his servants" and "servants were...expected to accompany the family to church services...had no liberty to indulge in enjoyable or personally productive leisure activities" $(75,74)$. The likelihood that Tituba spent much time doing anything without Reverend Parris's watchful eye nearby is unlikely. Why is Tutuba regarded as the one who brought witchcraft to the children then? I would argue for three primary reasons: her cultural background and otherness, her responsibility for the mischievous children, and her willingness to assist in folklore magic.

The understanding of New Englanders about Native people was based on their experiences with and fears of captivity and terror from tribes like the Wampanoag, Pequot, Narraganset, Nipmuc, and Wabanki. King Philip's War occurred from 1675-1678, and memories of terrible raids and murders were fresh for colonists. Though the trauma caused by the colonists was equally, if not more so, terrible for the Native people, New Englanders regarded the Indigenous people as heathens and savages who worshipped the devil. Norton even argues that, "The association among Indians, black men, and the devil would have been unremarkable to anyone in the Salem Village" (59). Though Tituba was not associated with these tribes directly, she was an easy target to pin the blame on for the devil's entrance to society. Eventually, "Tituba admitted to having learned about occult techniques in Barbados" and claimed her mistress had taught her (Breslaw 109). This would have been easy for the Salem villagers to believe based on their narrow view of cultures and religions other than their own and their fear of any worship which deviated from their own model.

The second reason that Tituba may have been the first woman accused is that she was considered responsible for the children of the Parris home. According to some scholars, two of these children did the unthinkable (to their Puritanical father) and played a fortune-telling game, 
though other scholars like Mary Beth Norton disagree that this ever happened (23). Abigail, Parris's eleven-year-old niece, and Betty, his nine-year-old daughter, are said to have been playing a game with their friends (likely two of the other main accusers, Mercy Lewis and Ann Putnam Jr.) where an egg was dropped in a glass with hopes that the shape would show them their future husbands. According to Salem lore as depicted by the Travel Channel Documentary about the Salem witch trials, the yolk took the shape of a coffin, startling the girls. They argue that that the wild symptoms of bewitchment began after this occurred. Whether or not this is true, it represents the legends that popular culture has promoted. Because Tituba's role was to watch the children and make sure they behaved, she was easily blamed for allowing them to play such a game.

Perhaps the making of the witch-cake proved the most direct reason for blaming Tituba for bringing witches to Salem. Making a witch-cake was an act of old folklore magic that was intended to act as a counter to dark magic. The process was to take the urine of the bewitched person and bake it into a cake of rye. The cake was then fed to the dog with the intention to cast the evil spirits out of the person and into the dog. Parris's neighbor, Mary Sibley, suggested to Tituba that she make this cake in order to cast the devil out of the girls. After Parris discovered that Tituba had assisted in conducting this counter magic, he was furious and beat Tituba, claiming she had brought evil into the home (Norton 27). Breslaw explains his actions: "By blaming Tituba for the misfortune of his family, he was able to uphold the stereotype of the Indian as Devil worshipper while distancing himself from the taint of association with the evil force she represented" (112). This would be important for Parris because, as Richard Godbeer explains in his article, "Your Wife Will Be Your Biggest Accuser: Reinforcing Codes of Manhood at New England Witch Trials," the men most likely to be accused of witchcraft were 
those closely associated with a female confessor. For all of these reasons, we see the likelihood that Tituba would be blamed for beginning the witch craze in Salem. Yet most significantly, Tituba was vulnerable to these accustations because of her role as a woman, person of color, and slave in a patriarchal colonial society. She had no rights or esteem in the town-she is powerless to the weight of these accusations.

In The Crucible, Miller does not use these same instances, but rather exoticizes Tituba's magic. At the beginning of the play, Parris sees Tituba over a cauldron. He accuses her, "I saw Tituba waving her arms over the fire when I came on you...And I heard a screeching and gibberish coming from her mouth. She was swaying like a dumb beast over that fire!" (Miller 334). Parris's accusation of Tituba depicts her as not only a foreign witch, but as a "beast"-reducing her to nothing but an animal, something to be feared. Miller also indicates that Tituba gave Abigail chicken blood to drink to curse John Proctor's wife. Abigail cries out against Tituba, "She makes me drink blood!" In Miller's depiction, Tituba even affirms this, "I give she chicken blood!" This intense and scandalous witch act makes her compact with the devil seem like a genuine possibility in the play. Tituba, who was already an easy target for the blame, is thrown into the fire as the main instigator of magic in Miller's play. Likewise, her broken English and "Barbados songs" indicate that she is a foreign woman who brings the dark magic with her from a mysterious otherworldly culture.

The mystery of the Salem witch panic has haunted scholars for ages. The desire to explain the phenomenon is inevitable, and many have put forth their best explanations, from bad rye bread to post-traumatic stress disorder (Schiff 4). As humans we seek to find reasoning for tragedies like the Salem Witch Trials, often at the risk of blaming the innocent. Miller's explanation for the trials places the blame on women. Abigail Williams's sexual drive and lust 
over John Proctor initiates the trials, and the magic itself comes from the foreign witch, Tituba. This blame adds to a long history of fear of a woman's sexuality and fear of the foreign.

Through most of Western history, power lies exclusively in the hands of men. Likewise, the art that comes out of a historical period reflects those in power at the time. Not only does the information we know of the trials come primarily from the men involved (though women were most affected), the history of the trials is also transformed through Miller's retelling. Rather than a tragic piece of history where women old and young lost their lives, Miller makes the trials a male narrative about conquering female temptation. This continues to happen today as narratives of the oppressed are appropriated to benefit the oppressors. Appropriation of the Salem witch trials by men is apparent in Miller's work but does not stop in the 1950s. Modern depictions of the women of Salem continue this cycle by playing to a male gaze and agenda as will be explored in the next chapter. 


\section{CHAPTER II: BLAMING FEMALE SEXUALITY AND BLACK MAGIC}

Miller's transformation of the trials into the battle against female and foreign malevolence has echoed throughout popular culture depictions of Salem since its publication. Even in contemporary culture, which claims to be empowering women and abolishing xenophobia, the Salem witch trials are still surrounded by sexual allure and exotic witchery. The movie adaptation of The Crucible remains close to Miller's narrative, while other productions, like Salem and American Horror Story: Coven, stray from his model. Regardless of direct reference to Miller's story, these contemporary portrayals follow his model of ignoring and distorting historical fact and sexualizing and exotictizing real women. The highly gendered roles affirmed by Miller's play continue to be seen in representations of the women of the trials, and the truth of the trials continues to be appropriated for the male gaze. In this chapter, I will expand upon the ways modern depictions of the Salem witch trials sexualize women to fulfill male desire, specifically in my analysis of the movie adaptation of The Crucible and the television show, Salem. I will use Laura Mulvey's analysis of the male gaze to deconstruct these shows. In analyzing American Horror Story: Coven, I will argue that these adaptations continue Miller's pattern of appropriation by fetishizing and villainizing women, especially Black women.

\section{Blaming Female Sexuality}

Female sexuality has been demonized for centuries. In the Bible, the root of the Puritan ideology that controlled Salem, women are blamed for the fall of mankind because of their inability to resist the devil's temptation. In her book, Witches, Sluts, and Feminists, Kristen J. Sollee states, "Christian women were indoctrinated with narratives about the lurking evils of 
womanhood from their youth, so it stands to reason they could succumb to the belief that they, too, were the Devil's handmaidens" (25). Depictions of women during the witch trials fed into this doctrine. There are graphic portraits from the era of women having sexual intercourse with the devil—-these women are labeled as witches. Sollee explains this connection of witchcraft and female sexuality in both history and contemporary culture: "For centuries, the word "witch" has been used to punish women and to police female sexuality" (13). An exploration of one of the most infamous texts within the witch hunting era, The Malleus Maleficarum, confirms this link. According to Sollee, this book, which became the ultimate guide in witch hunting, states, "All witchcraft comes from carnal lust, which is, in women, insatiable" (23). While men were also accused of being witches, women were in the majority of the accused for this reason. Witchcraft has been attached to female sexuality since the witch hunts' beginnings, and this clearly makes its way into Miller's writing.

In Laura Mulvey's essay, "Visual Pleasure and Narrative Cinema," she explores the concept of scopophilia in film. She defines scopophilia as, "pleasure of looking at another person as an erotic object" (Mulvey 67). Mulvey argues that the way women are depicted in film is an indulgence of male scopophlia. Women are portrayed as sexual beings to be possessed by male characters. By seeing a reflection of himself within the male characters, the male viewer can possess the woman as a sexual object as well. This act of implementing the male gaze in film can be seen in the following examples of films and television shows about the Salem witch trials: The Crucible (1996) and Salem (2014). The sexualization of women echoes Miller's acts of pinning the blame for the trials on the shoulders of women. The women are not just portrayed as overly sexual beings, but also use their sexuality to manipulate a community into its downfall. These depictions represent the way society has aligned its perception of the Salem witch trials, 
but more so, they show again the appropriation of female trauma to satisfy the male agendas.

In The Crucible, the connection between witches and female sexuality is made

through Miller's depiction of Abigail Williams. Abigail Williams is depicted as a seventeen year old girl who is the niece of Reverend Parris of Salem. She is portrayed as temperamental and seductive with "an endless capacity for dissembling" (Miller 9). She is obviously the leader of the group of girls accusing people of witchcraft in Salem in the play. She even threatens the other girls from confessing, saying, "Let either of you breathe a word, or the edge of a word, about the other things, and I will come to you in the black of some terrible night and I will bring a pointy reckoning that will shudder you" (Miller 20). Along with her hardened and cruel personality, she has sexual sin attached to her name. She had an affair with a married man in Salem Village named John Proctor. When he attempts to tell her he will no longer sleep with her, she continues to seduce him. She says, "I know how you clutched my back behind your house and sweated like a stallion whenever I come near!” (Miller 22). When he continues to refuse her, she will not accept it. Soon after, Proctor's wife and eventually Proctor as well are accused of witchcraft by Abigail. Miller makes it clear that Abigail accuses Goody Proctor out of lust for John, in hopes he will abandon his wife once she is outed as a witch. In this way, Miller blames the downfall of Salem on Abigail's sexuality, reinforcing patriarchal control and shame in the play.

This approach is unsurprising considering Miller's culture of the 1950s that scorned women for premarital sex while giving men a free pass. This is obvious through social, political, and medical practices of the 1950s that labeled "promiscuous" young women as the primary cause for unwanted pregnancies, venereal disease, and even rapes. In the book, Good Girls by Amanda Littauer, she describes the condemnation of parents and experts in the 1950s and quotes a study where a parent said, "It's the girls' fault, this early dating. They grow up too fast. Dress 
and live faster" (130). This culture of blame and shame of female sexuality likely influenced Miller's shaping of the female characters in his play, which continues to find its way into more modern depictions of the Salem Witch Trials.

In these modern depictions, this view of evil female sexuality is emphasized by casting choices. The film version of The Crucible produced in 1996 is directed by Nicholas Hytner and stars Winona Ryder as Abigail and Daniel Day-Lewis as John Proctor. The casting choice of Winona Ryder contributes to the sexual perception of Abigail, because Winona Ryder was a well-known actress at this time who had already played the leading lady in many other films including Heathers, Bram Stoker's Dracula, and Edward Scissorhands (IMDB). Before The Crucible, she had already established a reputation of playing an unconventionally beautiful character with a dark side. She was often typecast as the "femme fatale" as described in chapter one. In Marvin Carlson's book, The Haunted Stage: the Theatre as Memory Machine, he presents his theory of "ghosting," the idea that theatre will always be impacted by remembrances of past performances. This argument can specifically be applied to typecasting. Continuously casting a certain actress in similar roles can carry the impression of her into other performances. In this instance, because of Ryder's previous work, audiences are more likely to associate her character with female deception. Abigail, already matching the femme fatale persona, became another one of Ryder's sexy, brooding roles. Though she may be dressed like a Puritan, Ryder's legacy as a glamorous object satisfies the male gaze. Likewise, the casting of Daniel Day-Lewis, creates in viewers a "more perfect, more complete, more powerful ideal ego" for male viewers (Mulvey). Day-Lewis was known for playing dashing, heroic gentlemen before his role in The Crucible; he starred in movies such as The Last of the Mohicans (1992) and The Unbearable Lightness of Being (1988). In The Crucible he is portrayed as rugged and brooding, and as in 
Miller's play, comes out the hero who has conquered the temptation of a woman's evil wiles. Another way the movie's casting promotes the sexualization of Abigail is by downplaying the age gap between Abigail and John. While the actual Abigail Williams was eleven at the time of the trials, Miller's Abigail is seventeen. To a twentieth century audience, casting a seventeenyear-old walks a fine line of acceptability. However, if Abigail is not portrayed as a young girl, she can assume guilt for the affair while John Proctor is free of shame. By casting Ryder, who was twenty-five at the time of the movie's release, Abigail is played by an older and more womanly actress who can situate as the object of male desire without provoking guilt. This womanly lust makes the blame on Abigail's shoulders acceptable; she caused the affair, she caused the accusations, she caused the tragedy of Salem.

Visually, the movie surrounds the female characters with darkness, intrigue, and sexual symbolism by including additional scenes in the movie that are not found in the play. The first scene of the film, which is not found in Miller's play, depicts Abigail waking up her cousin and meeting the other girls in town to conjure spells with Tituba. There are shots of the girls running and giggling together as they go deeper into the misty forest to do their forbidden fun. Tituba welcomes them, and they stand in a circle, anxious to see the magic she will perform. Tituba sways as she sings her "Barbados songs" and mixes items into a cauldron. The spells that are conjured are love spells to make boys and men in town fall in love with the girls. As the girls drop their magical offerings into the cauldron, they speak the names of the men. The girls tease Abigail saying, "Give her John Proctor again, Tituba," and showing that Abigail's sexual escapades are no secret. Tituba takes a live chicken and swings it around her head, ready to put in it the cauldron, when Abigail whispers in her ear. In broken English, she says, "No, Abby, that bad thing!" Out of impatience, Abigail takes the chicken, breaks its neck and smears the 
chicken's blood across her face. The girls scream and begin to dance wildly, letting down their hair and stripping their clothes. As Reverend Parris approaches the scene, a woman's naked body is seen from behind. The naked girls dancing represents the use of unbridled sexuality to defy patriarchal forces, which is immediately deemed a great sin by the reverend. The women not only break the rules of performing witchcraft and dancing, they also commit the sin of rejecting the patriarchal control of a woman's sexuality. The depiction of the naked women in such close connection with the symbols of stereotypical "evil" witchcraft including the drinking of blood, the sacrifice of an animal, and the casting of deadly spells, makes one consider that the movie also aims to associate the liberated female sexuality shown by the dancing women with sin. Through these images, the occurrence of witchcraft in Salem is associated with the lust of the young women. Likewise, it fulfills the scopophilia of male viewers, who know the sexuality will soon be punished.

Another way that The Crucible movie contributes to the blame of female sexuality is through the physicality between Abigail and John when they meet in the movie. Unlike many of the movie's other scenes between John and Abigail, this scene is found in Miller's original text. The shot shows Abigail sneaking up to John from around the corner of the barn. When they speak, they stand close to each other, and she leans against the wall, sighing with desire. She appeals to John and speaks to him of their sexual history using the same words from the play. Unlike the stage directions indicate in the play, however, she then kisses him passionately and sensually reaches for him. This blatant desire for sexual relations through the physicality shown on screen strengthens the connection between the witch trials and Abigail's sexuality by explaining her lustful motive. In a later scene that is not found in the play, Abigail attempts to force John to touch her sexually, and he responds by shoving her away. She warns him that he 
will regret his mistreatment of her. Later, another scene is added to the movie, after John has been accused and imprisoned. Abigail begs him to run away with her so they can be together. The movie makes it continuously apparent that Abigail's intention for starting the witch trials is to win John's love. John's larger struggle with the government of Salem is represented through his struggle with Abigail. When Salem's leaders beseech him to save himself and sign a confession to witchcraft, he is tempted to confess. However, in doing so, he loses his integrity and honor (according to Miller), so he resists and is led to his death. To make this decision, he must expel the temptation to surrender to the entreatments of those who claim to care for him. Abigail claims to love him, and begs him to give in and save himself; so do the leaders of the town. Female sexuality becomes not only the catalyst for the trials but a metaphor for temptation and control. The movie clearly appeals to a male audience who long to place themselves in Proctor's role by not only lavishing in the sexual attention of Abigail, but also dominating and punishing her as the villain.

Female sexual temptation and power continue to be associated with the Salem witch trials in other representations as well, even those that don't discuss Abigail specifically. In the television show, Salem, there is no Abigail Williams mentioned. However, the main character, Mary Sibley (named after another real woman of the Salem trials) is portrayed as a dangerous sexual being. Both of the main characters of the show, Mary Sibley and John Alden, were real people living in Salem and associated with the witch trials. However, the true figures are related in name only to the show's characters. Salem creates an entirely fictional plot for Mary and John that does not even remotely resemble known history. Numerous other historical names are associated with the show's characters including Mercy Lewis and Cotton Mather, but it is important to note that the show is fully fictionalized. 
The first episode of Salem introduces the idea that the problems in Salem are centered on sexuality before witchcraft even enters the town. The first scene of the series begins with a man and woman in the stocks being whipped and humiliated as the man is branded as a “fornicator”. Quickly afterwards, Mary Sibley and John Alden's relationship is introduced as they secretly exchange a kiss in the night. Soon we find that Mary is pregnant with John's child, though they are unmarried with no intent to wed, a great sin in Puritan society. In an attempt to avoid her own punishment, she is led into the forest by the show's sexualized version of Tituba, where she performs an abortion. Mary's abortion is beyond physical, however. It is a spiritual abortion: a sacrifice that sells Mary's soul to the devil in order to gain power and prestige. Again, feminine vice brings evil to Salem, this time through a woman exercising her autonomy over her body and her place in society. When Mary chooses to accept this abortion, which is presented more as a paranormal phenomena than a physical procedure, she allows the devil to enter Salem through her.

The connection between pregnancy (or lack thereof) and evil is a long-standing one. According to Sollee, in The Malleus Maleficarum, one of the most important sources during the witch hunts, there is a chapter titled "That in Various Ways Midwife Sorceresses Kill the Fetuses in the Womb and Cause Miscarriages, and When They Do Not Do This, They Offer the New Borns to Demons" (39). Because the female body is considered inherently evil—based on the Christian perspective of the first woman, Eve, bringing sin into the world — and only women can have children, the act of childbirth has often been related to evil and witchcraft. For instance, many midwives in Europe were executed as witches. In Sollee's book, she says, "During the witch-hunting era, the female figure most intimately acquainted with sex, birth, and fertility was the midwife. Armed with knowledge of herbology, biology, and in particular, reproductive 
health, these predominantly poor, peasant women were easy targets for accusations of sorcery" (Sollee 39). In another play of the twentieth century, Caryl Churchill's Vinegar Tom, a local witch is contacted by a young woman to help her end her pregnancy. When the town discovers this, both the woman and the witch are deemed witches and tortured.

To a modern audience whose society has a long history of conflict about abortion rights, this parallels many conservative mindsets that believe abortion is the cause of evil in America. Sollee argues that the persecution of women giving and seeking abortions is far from over. She says, "like the inquisitors, witch finders, and civilian accusers of yore, Republican lawmakers and their ongoing attacks against sexual and reproductive health place a woman's right to bodily autonomy perpetually under siege" (43). For an audience familiar with this demonization of women's reproductive rights, the abortion in the first episode of Salem continues the attachment of the characters to great evil. In this way, Salem uses the witch trials to symbolize the downfall of America and placing blame on women who take control of their own bodies. Rather than recognizing the suffering religious oppression brought to the town of Salem, especially women, the creators of the show continue Miller's tradition of appropriating female pain for male agendas.

Beyond this abortion, we see other indications of the villianization of woman's bodily autonomy through Mary's sexuality. Not only does Tituba promise Mary with the abortion that she will escape the scorn of being an unmarried mother, she also promises her that if she allows witchcraft into Salem, she will be regarded as the most powerful woman in town. Mary gains this power through sexually manipulating the wealthiest man in town into marrying her, then taking control of him. Her sexual prowess is seen in her seduction of the men around her and accounts for the downfall of Salem's leaders. As the show continues, John Alden returns and it becomes 
clear that the plot is centered on the relationship between Mary and John, as well as various other sexual relationships and indiscretions. A final indicator of the sexual nature of the show is found in the costuming. The actresses in the show are dressed in sexy, revealing clothing, even as peasants and Protestants. They are adorned in blacks and reds, with corsets accentuating their cleavage. This is one of many ways Salem continues to situate female sexuality as the center of the Salem witch trials. Even though the show does not connect directly to The Crucible, the same theme of scornful female sexuality that Miller established prevails. The story of the oppression of innocents becomes a tale of hyper-sexualized vice; history is entirely ignored and misused to satisfy the male gaze.

\section{Blaming Black Magic}

Studying the popular culture representations of Salem witch trials opens another discussion on the appropriation of female suffering - the suffering of Black women. In The Crucible (1996), Salem (2014-2017), and American Horror Story (2013), multiple women are blamed for their role in the trials, but the greatest victim of this heaping of shame is the character of Tituba. As a Black woman, she is portrayed as wicked and unholy, but she is also deemed by creators of these shows as unworthy for a full storyline and dynamic character development. In Miller's play and these more recent representations, Tituba is given the blame of ushering witchcraft into Salem, but not given the power that seemingly comes with it for the white women portrayed in the story. The character of Tituba has the power to bring evil but as a Black woman is still disenfranchised as that power is stolen by the white characters.

In the movie version of The Crucible, Tituba is blamed directly for bringing evil to Salem, because she is not just implicated in the witchcraft but is actually seen performing it. In 
the opening scene, she rounds up the circle of young girls, laughing maniacally. As they speak the names of the boys they want, she invites them each to toss a plant into her cauldron, reminiscent of traditional western witch stereotypes. She begins to sing a "Barbados song" and to sway back and forth. Both of these images evoke an essence of dark magic and foreign power. The next shot shows her swinging the chicken around her head, preparing it for Abigail, who then smears the chicken's blood on her face to speak a curse on John Proctor's wife. This animal sacrifice is reminiscent of voodoo stereotypes and makes Tituba look like a real witch who has tainted the young girls. In this way, she is unlike the white women in the movie who are naive to dark magic. The scene sexualizes the young women and places an enslaved Black woman at the center of this sexualization which draws upon racists stereotypes of women of color as a sexual corruptor and "beast." While Abigail may be blamed for using her lust to fuel the trials, only Tituba's exotic evil can be blamed for starting the craze of magic in the first place.

This, however, does not give Tituba power or agency in Salem. She is not esteemed for her confession to witchcraft like the white girls, but is punished severely. When Abigail accuses her of being a witch, Parris beats an confession out of Tituba. She claims she does not work for the devil, but Parris as well as the audience are not convinced, because we have just seen her perform some form of dark magic in the forest. Whether or not she has a "compact with the devil," the movie makes it clear that she certainly practices witchcraft. This opening scene, which is mentioned as only a rumor in the play, is emphasized in the movie adaptation. I argue that this increases the allure and exoticism of the story and ultimately, the stakes of the movie. Rather than a story about young girls behaving poorly, the story becomes one of a demonic force brought on by a Black woman. Yet after Tituba's confession, she sinks into the background of the story. She is punished, then forgotten. We see a Black woman's suffering become a plot 
device, a crutch to keep white women from assuming full blame.

The television show, Salem, takes this blame of Black women a step further. The show centers on a witch coven in Salem led by a powerful young woman (Mary Sibley) that causes great turmoil, resulting in the killing of innocents through witch trials, which the coven controls. In the first episode of Salem, Tituba is introduced as a guide to the main character and eventual coven leader, Mary Sibley--a reversal of the roles of reality; the real Mary Sibley convinced Tituba to make the witch cake. The fictionalized Tituba offers Mary, a desperate woman afraid of bearing the shame of adultery in her Puritan society, a solution to her unwanted pregnancy. She brings Mary to the forest and promises her that if she gives herself to the devil, she will be free from the pregnancy and have all her desires met. Though Mary fights against it, Tituba coerces her into the abortion of the baby. This is not merely an abortion but rather it is a sacrifice and pact made with the devil. Through forcing this pact, Tituba brings demonic forces into Salem. Though Mary later relishes in her wealth and power, she still protests to Tituba that she does not want to work for the devil. Tituba scolds her and reminds her that she would be nothing without the devil's work. Tituba, in this depiction, works actively for the devil, inviting him into Salem. She is truly the instigator of the witch trials, but she is still not the one in power. She is Mary's servant and ultimately the devil's servant as well. Her role is to shoulder the blame of evil yet never obtain the power it brings.

Tituba is blamed for ushering in witchcraft in other television series as well. In the anthology series, American Horror Story, the season "Coven" portrays Tituba in a less direct way, but clearly associates her with dark magic. The television show depicts two covens of witches, one primarily white and one primarily Black. In the article, "Tracing Tituba through American Horror Story: Coven," Dara Downey explains the show's set-up, “American witches 
are both united as a single 'tribe' and starkly divided by race and ethnicity, a division that effectively structures the season as a whole" (16). The members of the primarily Black coven are considered descendents of Tituba and are led by the infamous voodoo queen of New Orleans, Madame Marie Laveau. On the other hand, the coven of primarily white witches are considered to be descendents of the witches of Salem. The story is that Tituba shared the practice of witchcraft with the Salem women who eventually avoided persecution and fled Salem, taking Tituba's craft with them, while Tituba and her descendants suffered. This history sparks a longheld feud between the two groups which escalates the plot throughout the season.

The descendants of Salem perform a witchcraft that resembles what most people would associate with modern depictions of witches. They cast spells and charms, and one of them can read minds. The one member of the coven whose magic takes a largely different form is the young Black woman, who is herself a human voodoo doll. She can inflict pain on others by causing herself pain. She eventually leaves her coven to join the descendants of Tituba. The Black coven's magic is less westernized in what most people associate with witchcraft. It is more exotic and takes the form of ritual dances and sacrifices as well as the summoning of a very creepy Gatekeeper of the Spirit World named Papa Legba who comes to Marie Laveau annually and demands the sacrifice of an innocent life. The difference in the portrayal of the two covens is drastic — even though they both perform violent magic. The colors are darker and earthier in the shots of the descendents of Tituba, while the descendents of Salem are portrayed in very clean white spaces and are usually wearing sharp black outfits. The white witches are portrayed as elite, and the Black witches are portrayed as savage.

This series shows a very clear misconception of Tituba that is being perpetuated in popular culture. By surrounding her descendants with voodoo, the show's creators fall into the 
same myth that Miller began: that Tituba brought witchcraft to Salem from her exotic home to usher evil into young America. To amplify this further, the show clearly situates the descendents of Tituba as the antagonists of the plot. While eventually the two covens must join forces to fight witch hunters, most of the show's early conflict is between the descendents of Salem and Tituba. Because the protagonists of the series are members of the Salem coven, Tituba's descendents are depicted as villainous and dangerous. Downey says of "Coven" and Salem, "the lacunae and misconstructions that make up the history of depictions of Tituba are at once addressed, perpetuated and exploited for dramatic effect in these shows, and in AHS: Coven in particular (18)." While the shows do not claim to be historically accurate by any means, they utilize misunderstood history to create their own riveting story lines, much like Miller. Even within these fictional storylines, however, we see the real precedent of white people appropriating both the work and struggles of Black women. The Salem witches not only stole the witchcraft from Tituba, but the Black witches are also killed off in the plot instead of the white witches.. Towards the end of the season, a witch hunter attacks the Black witches' hideout, a beauty salon, with an assault rifle. Rather than the white witches suffering, the Black witches take the fall—fulfilling the male need for women to be punished for their crimes.

I argue that the turning point in popular culture's depictions of Tituba was the publication and popularization of The Crucible. Miller's play exoticizes Tituba's magical background and abilities and blames Salem's witch craze on her introduction of witchcraft into the Puritan world. This depiction not only villainizes an innocent and oppressed woman, but also uses her race to fetishize a culture for its "dark magic." However, this blaming of Black women does not begin or end with The Crucible. These depictions of the witch trials are examples of appropriating women's but more specifically women of color's experiences of suffering to fulfill a male gaze. 
As women playwrights have gained more of a voice in recent years, however, this appropriation has been examined through a feminist lens and called out for its misogyny. In the next chapter, I will explore three plays written by women between 2018-2020 that seek to reframe and redeem the story of Salem. 


\section{CHAPTER III: A FEMINIST RESPONSE}

The Crucible distorted the popular perception of the Salem witch trials and placed blame on women. Through the examples of the previous chapter, it is clear that there are patterns of this interpretation that have been repeated in pop culture media. The Crucible has provided a misogynistic and racist model that many artists have emulated in their own works about the Salem witch trials. Male creators have appropriated the story of female suffering and persecution for their own agendas whether for pleasure or political gain. This unfortunately continues today as men in power use the witch hunts as allegory for sexual assault allegations. I believe that Miller's work to associate women and their sexuality with the downfall of Salem has allowed this idea of appropriating witch hunts to become commonplace. The 2016 election of President Donald Trump is yet another example of how authority figures doing this perpetuate sexism and misogyny. Whether using social media to tweet vicious remarks about women or supporting policies that actively revoke women's rights, Trump aimed to police female bodily autonomy, to discredit women in leadership, and denigrate women who challenged his authority. He has been accused of sexually assaulting twenty-five different women. These alleged crimes and those of men who have been convicted of rape and sexual assault, such as film producer Harvey Weinstein and actor Bill Cosby, have highlighted the realities of sexual violence committed by men in power. Likewise, accusations of powerful political officials including Supreme Court justices Clarence Thomas and Brett Kavanaugh, Congressman Al Franken, and New York Governor Cuomo display the ever-growing public outcry to end sexual abuse. Women have taken to social media with the \#MeToo movement to encourage survivors of sexual assault and harassment to share their stories and raise awareness and community for these survivors. The 
\#MeToo movement was founded by Black activist Tarana Burke in 2007 and has provided a healing community for survivors and provided resources to promote their well-being. In 2017, the movement gained nationwide attention after white actress Alyssa Milano began the hashtag that encouraged women to share their stories of sexual assault (Garcia). From this, many cases of sexual harassment have come to light, including prominent politicians.

The response to this from Republican lawmakers has been aggressive and defensive. Their responses echo the accusations of both the Salem trials and McCarthyism that deem women as witches, liars, and whores. Like Miller's portrayal of John Proctor, men, specifically white men, consider themselves victims of injustice for being called out for their crimes. In the article, "Donald J. Trump and the rhetoric of ressentiment," Casey Ryan Kelly explains, "white victimhood rhetoric is largely unconcerned with adjudicating the structural nature of injustice. The long-standing effort to paint white Americans, white men in particular, as victims erases the material distinction between real structural inequality and indignation that arises from felt intensities" (8). This idea of the white man as the victim was seen especially during the trial of Supreme Court justice, Brett Kavanaugh. Rather than empathizing with the woman Kavanaugh assaulted, conservative supporters claimed that the judge was being treated unfairly because of a liberal trend.

In response to this victimized backlash to the \#MeToo movement, Katie Gentile in the article "Give a Woman an Inch, She'll Take a Penis," explains that many of these leaders have equated sexual assault charges to a witch hunt. She contextualizes the inappropriate nature of this term: "Witch hunt might feel an appropriate term because there is a similar manic quality, but witch hunts targeted women who had overstepped heteropatriarchal boundaries" not men who committed acts of violence on the female body (242). Even Trump himself has referred to any 
anti-Trump rhetoric as a "the single greatest witch hunt of a politician in American history!" which is a blatant misunderstanding of history and the 16th and 17th century witch trials' unique and targeted persecution of women (Harriger 181).

Trump's use of "witch hunt" to describe American politics is not a first, as we have seen in these previous chapters. Arthur Miller wrote The Crucible as an allegory for his own experiences with government "blacklisting" for communism in Hollywood. However, I argue that in the process, he created a model set by The Crucible, which blames a man's downfall on the lust and revenge of a scorned woman, that Trump and others draw their modern parallels to the witch trials of New England. Miller makes the history of witch trials that killed thousands of women around the world into one of male victimhood and female malice. This revised history continues to shame and police women in the misogynistic, Trump-era culture of today.

However, this is not the only way Miller's play has set the framework for the story of the trials. The Crucible has recently been used conversely by contemporary playwrights to address these long standing issues of sexism. Women playwrights are reclaiming the narrative Miller created and using it to confront sexism head on in his work, life, and influence in American culture. By exposing the play's disparaging portrayal of women, these playwrights are able to connect the misogyny of the Puritans in the 1600s, of Hollywood in the mid-20th century, and of the politics of today. The plays, Abigail by Sarah Tuft, John Proctor is the Villain by Kimberly Belflower, and Becky Nurse of Salem by Sarah Ruhl discuss The Crucible in light of modern issues by placing its performance in a contemporary setting. While the plays' goals are not necessarily to correct or demand historical accuracy, these plays still shed light on the gaps and discrepancies in Miller's text and their continued effects on popular culture. All three plays expose what society has chosen to accept as the norm in both the witch trials and women's lives 
in general and to expose the way men have appropriated the suffering of $17^{\text {th }}$ century women and modern women to achieve their own goals and desires. All three of the plays end with a call to action for women to create their own works that redeem the women of Salem and modern women living under the oppression of the patriarchy.

In the play Abigail by Sarah Tuft, a male director recently accused of sexual assault decides to stage a production of The Crucible in order to make a comeback in society. A famous male actor, who is at first hesitant to work with the director again, is cast as John Proctor, and a young, cute internet sensation, Ashley, is cast as Abigail Williams. Though expecting her to be ditzy and naive, the director quickly finds that Ashley is headstrong and curious. She comes into rehearsals with questions and concerns about the script, criticizing Miller for his sexist portrayal of women. Soon Ashley also connects what she learns of Miller's personal life to the text and critiques his misogyny towards his former lover and salacious Hollywood icon, Marilyn Monroe, and its relationship to the play's characters. Rather than encouraging her curiosity, the director and other cast members are frustrated by her concerns. The director offers to work on the play with her personally, but he instead gets her drunk at his home and assaults her. She is at first ashamed about the incident but as she continues to connect with the oppressed women in Miller's script, she becomes empowered to speak her truth. She reveals the rape, quits the play, and writes her own one-woman show about Miller's disparaging of Abigail Williams and Marilyn Monroe.

Kimberly Belflower's play, John Proctor is the Villain, also links The Crucible with sexual assault on women's bodies. The play takes place primarily in a high school English classroom where students are reading The Crucible in 2019. A group of students want to form a feminist club but are discouraged from doing so because of recent sexual assault allegations in 
their community. The school counselor calls it "a tricky situation with everything that's been going on in the community... people are-tensions are high" (Belflower 10). The students are finally granted their club when their male English and sex education teacher volunteers to be their sponsor if they use it as an opportunity to discuss The Crucible too. The discussion of The Crucible becomes very personal when a student's father is accused of assaulting multiple women, then even more so when it is revealed that the English teacher has preyed on many of his students, including two in his class.

Becky Nurse of Salem by Sarah Ruhl does similar work in connecting The Crucible's sexism to modern instances of injustice. Becky Nurse is a tour guide at the Salem Museum of History who rarely uses the "script" they give her. She claims to know the history better than anyone else, because she is a descendant of Rebecca Nurse, one of the executed women. This gets her in trouble, however, and she loses her job. Things quickly go awry when Becky is arrested for stealing the wax statue of Rebecca Nurse from the museum. Meanwhile, Becky's granddaughter is in a high school production of The Crucible where she and other girls are sexually harassed by their director. The play ends with them sharing a post-performance ice cream cone and reflecting on the women before them whose lives have been sacrificed literally and figuratively by the trials and by popular culture.

Each of these plays works to expose the historical inaccuracies Miller uses to accomplish his sexist goals in The Crucible. For instance in Abigail, Tuft addresses the age gap between Abigail and John through Ashley's curiosity to learn more about the true events of the play. Doing this in a contemporary setting shows just how inappropriate the creation of the affair between John and Abigail is, especially through a modern lens. She says, “Abigail’s desperately coming on to Proctor like some sort of unhinged seductress. I mean, Proctor and Elizabeth 
literally refer to Abigail as a "whore" eight different times...But you know what? In real life, Abigail Williams was eleven years old. Eleven. John Proctor was sixty" (Tuft 31). While the other actor playing John Proctor is shocked, the director and his wife merely brush it off as an artistic liberty. Ashley describes the play as "inherently misogynistic" and argues with the director about its role in modern society (26). By taking Miller's changes out of the context of the play and into the world of 2019, Tuft illuminates the crude deception of Miller's choices. Ashley's disgust for these discrepancies Miller created expresses Tuft's argument for a revised look at The Crucible with a feminist perspective that considers the harm of a white male gaze.

Beyond the changes to Salem's history, Tuft also addresses Miller's personal agenda behind The Crucible. While it is widely known that Miller wrote the play as an allegory to the Red Scare, the knowledge of Miller's more personal ties to the story are lesser known. As Ashley says, "it's a bad allegory" (Tuft 34). Her thorough pre-rehearsal research on The Crucible reveals to her and the audience that Miller's personal life permeates every inch of the play, but specifically through the affair between John and Abigail. At the time he wrote the play, Miller was attempting to return to his wife, Mary Slattery, after having an affair with Marilyn Monroe (Abbotson 18). Ashley connects the two saying, "Abigail is Marilyn. So by making her hypersexualized and the aggressor, he's saying his infidelity is all her fault, not his. He's projecting his shame onto his invention" (Tuft 36). She explains further that what she learned from Miller's biography showed her just how much Monroe was demonized by Miller. The play delves further into Miller's treatment of Marilyn Monroe and his depictions of her on stage and screen. Ashley describes the movie The Misfits that Miller claims to have written for Monroe that sexualizes her pain and sadness. She also describes the role Miller modeled after Monroe in his play After the Fall where he realizes she is a "whore" (Tuft 40). Ashley uses these disparaging 
portrayals of Monroe as supporting evidence to argue that Miller wrote the play with sexist intentions. Beyond his political agenda, Miller also appropriates the stories of the women of Salem to shame women in his own life. He attempts to clear himself of guilt, like John Proctor, by demonizing a character representative of Monroe.

Abigail also addresses a concern that I myself have encountered writing this thesis. Miller is regarded as one of the greatest American playwrights, and for many scholars and audiences, The Crucible is the quintessential American play. In fact, many regard his work as almost a sacred text. Even the character of the director's wife in Abigail says of Arthur Miller, "The man was a god." Denying the artistry that has earned Miller his prolific role in the canon would be both a disservice and irrelevant to the argument. Miller, though a highly regarded artist, is still human thus still has personal biases and agendas that make way into his writing. Deeming him or his work as infallible is a flawed way of thinking as it does not allow for the necessary feminist deconstruction. In Abigail, both men and women defend Miller when Ashley calls his work sexist. Tuft uses this part of the play to show that glorifying Miller beyond reproach is to contribute to the oppression of women and their stories. This can be applied to other representations of history as well and asks us to question why we allow powerful men and what they deem as truth to live beyond reproach.

In a similar way, Becky Nurse of Salem addresses and condemns these pseudo-historical changes made by Miller that show his misogynistic agenda. The play begins with Becky giving a tour to a group of high school students at the Salem Museum of Witchcraft. She begins by introducing herself as a descendant of Rebecca Nurse, a fact she is very proud of, and leads them around the museum. She stops at a wax figure of John Proctor and briefly explains the plot of The Crucible to the students. She calls it, "our goddam Christmas pageant in Salem," then begins 
to explain its historical inaccuracies, specifically noting the relationship between John and Abigail (5). She scoffs at the idea that Abigail could possibly be seducing John. She says, "Now, in the play, the reason Abigail wanted to get revenge on John Proctor's pregnant wife (this is what I could never really wrap my head around) is that this young girl wants to fuck an old man...More likely that John Proctor molested...Abigail" (6). These "editorial" notes made by Becky are later the cause of her removal from the tour guide job. Though she is correcting popular culture's misconceptions of history, the public does not want to accept the true history, thus she is reprimanded and eventually fired from her job. Though she is right, Becky makes the story less palatable for the listeners. Additionally, her language on the subject is crude. Even though the subject itself matches the vulgarity of her language, she still loses her job for choosing indignation over decorum. By showing Becky getting fired for this, Ruhl shows how intrigue is valued greater than truth, especially in regards to the Salem witch trials. She also calls out Arthur Miller for allowing the young girl in his pedophilic plot to be considered a "whore" and the downfall of Salem. However, Ruhl also makes a unique point about human nature and society by expressing the ways people refuse to accept the truth when it is uncomfortable or places the cis white male as the oppressor. This is not limited to the Salem witch trials but rather spans throughout American history which is often glorified into a patriotic fantasy that eliminates the stories of the oppressed.

These plays go beyond calling out Miller, however. They also bring to light modern societal issues that echo Miller's misogyny. Abigail also uses The Crucible as a means to discuss contemporary women's issues, specifically the \#MeToo movement. The director of the play within the play has already been accused of sexual harassment when he decides to direct the play. He believes that he must redeem his name, like John Proctor, and believes directing The 
Crucible is the way to do this. Once Ashley reveals to the rest of the group that John Proctor would actually be a pedophile if Miller's story were true, it becomes even clearer how the stories parallel one another. The play uses Miller's misappropriation to the tell the story of sexual assault in show business, an issue that has become widely discussed in media. This includes a "rehearsal" between the director and the young actress where he rapes her. This rape leaves her insecure and lost, causing her to quit the play as well as her YouTube channel. Having painful material like this trauma centered around a performance of The Crucible associates the play with its own layers of sexism and abuse and mirrors the abuse of women in Miller's play. .She exposes the commonly used phrase, "witch hunt," as an appropriation of women's suffering. The very decision of the director to produce The Crucible is based on his belief that he is a John Proctor himself as his good name is smeared by villainous women. The Crucible is not even regarded as a story about the Salem witch trials. To him, the play is meant to represent men who must overcome the dangers of female sexuality and hysteria. In the play, the director even calls his own scandals a "witch hunt," equating paying for his crimes of assault with the murder of innocent women, men, and children. This common strategy of men to allude blame for their crimes is a shameful misappropriation of the deaths of over 10,000 women who were convicted and executed as witches through the $15^{\text {th }}-17^{\text {th }}$ century in Europe and America. It is a crime against the truly oppressed to allow their pain to be an allegory for male "victimhood" that is based in sexism and toxic masculinity.

In many ways, John Proctor is the Villain echoes the sexism of The Crucible as well. The connections between the atmosphere at the school and the atmosphere of 1600s Salem are apparent in the play through the religious zealotism and hypocrisy of both communities. While the 2019 school is obviously much less extreme than 1600 s Salem, there is a sense of religious 
oppression through the "purity culture" established in John Proctor is the Villain. The English teacher doubles as their sex education teacher which preaches abstinence instead of protected sex. The teacher reminds the students, "there will never be any kind of birth control that teaches faithfulness trust responsibility or commitment" and uses examples to convince students that the more they have sex with others, the less faithful they are to their eventually partner (Belflower 41-42). Despite preaching this to his students, he has had sex with multiple young girls in his classes over his years as a teacher. The hypocrisy and sexism of purity culture is intertwined deeply with the class reading The Crucible. In this way, Belflower illustrates how The Crucible not only places men at the center of the story but is also used by men to perpetuate sexist ideals. Another way we see the studying and production of The Crucible continue a cycle of abuse is through the way the English teacher preys on his students. He uses the play to get close to his students by sponsoring their The Crucible centered feminist club and by having "afterhours" conversations with his female students. In these conversations, he plays himself as the victim of a witch-hunt, much like John Proctor. Also like Proctor, he calls into question the character of the girl making the accusation. This is supported by the perception of other characters in the play. She is called a whore by her classmates and is not believed by the school board when she attempts to report the crime. The characters use The Crucible as a weapon against the young girl by equating her (and the other women who come forward about abuse) to Abigail.

Ruhl shows another modern parallel of sexism in Becky Nurse of Salem when Becky watches the news on a TV at the bar and hears a Trump rally chanting "lock her up!" about Hillary Clinton. During the 2016 election, conservative Republicans used a scandal over Clinton's use of a personal email address for government work to condemn her as a "crook" and 
"criminal." Similar to the outrage against women and cry for their imprisonment in the Salem trials, conservative leaders today demonize powerful women. During the trials, this act of demonizing helped keep the powerful in power, mainly men. Kristin J. Sollee explains that one of the first reasons witch trials surfaced in Western culture was because at the time, women were dominating the medical field as midwives and herbalists. As modern medicine began to develop, men began to take over the field and found their work threatened by these women. Thus, they were deemed witches and murdered by the thousands in order to maintain male dominance in their field. Similarly, when a woman encroached upon the male-dominated territory of politics, Clinton was treated as a criminal. In fact, some even called her a witch. Meanwhile, Trump is accused of multiple crimes that have been brushed aside by his supporters. It is clear that just as women were more likely to be accused in the witch trials, the flaws of women today are amplified and broadcast more than those of men. Again, the witch trials are twisted by men into a story of a woman's criminality. Ruhl associates The Crucible with sexual exploitation in other ways as well. Gale, Becky's granddaughter, auditions for the local school's performance of The Crucible where she is cast as Betty. The director makes uncomfortable advances to the young women, encouraging them to dance naked in the woods for "character work," then show him pictures. Like the two plays analyzed earlier in this chapter, this play shows how The Crucible continues to be used as an abusive tool by men against women.

However, these plays do more than just associate The Crucible with sexism and abuse; they offer examples of women reclaiming the story of the witch trials that has been appropriated by men. Abigail concludes with Ashley's performance of a one woman show that exposes the faults of Miller and shines lights on the true history of Salem. She also exposes the director's malfeasance by using the technology her generation is familiar with, YouTube, to broadcast his 
unapologetic confession. In this way, Tuft encourages a new generation of feminists (which includes herself) to question the "greats," look for gaps in history where a woman's perspective has been largely ignored, and to create new works which illuminate the truth they find. Ashley does just this in her play, and this mirrors what the playwright herself is doing in writing the piece. Tuft encourages those who are outraged by learning the truth to find a way to communicate these truths to others. Unlike the other modern depictions of the Salem witch trials explained in chapter two, Tuft offers a model to reclaim the witch trials' importance to women's history by directly confronting those who appropriated it.

Like Abigail, John Proctor is the Villain has a redemptive ending. The class is assigned a creative project about The Crucible. Two of the students write their own script as Elizabeth Proctor and Abigail Williams. They treat each other with compassion, call out John Proctor for his crimes against women, and encourage the other students in the classroom to break out of the strict culture of their classroom by dancing wildly. In doing this, Belflower offers a chance for the women of Salem to be seen and recognized for their truth. Additionally, she calls out to women to create new works about the Salem witch trials and shows the inspiration a feminist adaptation can bring to modern society. Similarly, the troubling experience of the young actresses in Becky Nurse of Salem empowers them to make their own statement during the play about how sexist The Crucible really is and why it should be reexamined and its popularity rethought.

However, there is a very obvious lack of intersectionality in these plays. Intersectionality, a term coined by legal scholar, Kimberle Crenshaw, is defined as the unique intersection between racial and gendered oppression that women of color experience. In a 1991 article, Crenshaw defines intersectionality as, "the ways in which the location of women of color at the intersection 
of race and gender makes our actual experience of domestic violence, rape, and remedial reform qualitatively different than that of white women" (1245). Tituba's experience of the witch trials is certainly different than that of the other women involved. Her confession was prompted by being beaten within an inch of her life, which was already a life of enslavement and prejudice. While there is every opportunity to analyze the character of Tituba as well as Abigail, all three of these playwrights mention Tituba as merely an afterthought.

In Abigail, Ashley does mention Tituba's disparaged history. She says, "If you read up on the actual events, the real Tituba never actually led any wild sexy dancing in the woods. Never did voodoo with chicken blood. She was a slave who only "confessed" after being tried and brutally beaten. Many say she later recanted" (28). She expands by explaining that Tituba was not Black but rather Arawak. In noting this change, Tuft identifies Miller's reliance on popular American stereotypes about Black women as slaves-like the mammy stereotype mentioned in chapter one - to tell his story. The director and producer respond by arguing, "We have a very diverse cast" (29). This response echoes the very lackluster response of white Americans to racial injustice. By having a "color-blind" philosophy, no real equality is achieved. Rather, the true issues of oppression are hushed and dismissed. Tuft shows that having a "diverse" cast or portrayal of Tituba is not a remedy for Miller's racism in a production of The Crucible. While Tuft illuminates many sexist implications of The Crucible in her text, her mention of Tituba is brief. There is no actress playing Tituba in the play. Her history is mentioned only as an afterthought to Ashley's concerns about Abigail's portrayal. This play offers a white feminist perspective and lacks a complete intersectional approach to the analysis of Miller's play. With this in mind, we see that the feminist arguments made by Tuft in the play, while insightful about Abigail, are limited by their lack of inclusion of Tituba's experiences and ultimately the 
experiences of women of color. In the other two plays, Tituba is not mentioned at all.

This is alarming in that Tituba was the most vulnerable and disenfranchised person in the Salem witch trials yet the stories are centered on white women. This mirrors exactly what has happened within the \#MeToo movement. Black women may have started the movement and may be the most affected by assault and abuse, but white women center their own stories above those of women of color. While these feminist plays make strides towards an analysis of Salem centered on women's voices, they silence or glance over the voices of Black women. Feminism is not feminism if it does not include women of color. These plays are only a starting point and until our popular culture depictions of the Salem witch trials uplift the voices of Black women, we cannot do justice to the women who lost their lives or livelihoods in 1692 Salem and we cannot dismantle sexism in our own society.

There are two other plays that I am aware of that have been written in the last decade that depict the Salem witch trials from a feminist perspective and focus on Tituba, Tituba by Winsome Pinnock and Witch Hunt by Carol S. Lashof. These plays do an excellent job of amplifying the voice of Tituba with historical accuracy and by putting the power back into her hands. However, I decided not to include these works in my thesis, because they do not relate directly to The Crucible and ranged past the scope of my argument. These plays are about sharing history rather than exposing Miller's sexism, thus they are not included in this thesis. While there is feminist scholarship and creative work about Tituba, it doesn't directly dismantle the damage Miller has done as a pseudo-historian of the Salem witch trials.

The Crucible has become the foremost popular culture reproduction of the Salem witch trials. Its legacy is established not only in the role it plays in the literary and dramatic canon, but also in the recurrence of the tropes it creates in contemporary pop culture. This legacy can be 
analyzed as historically inaccurate, misogynistic, and racist because of its depiction of women as sexual, foreign villains. The contemporary plays by Sarah Tuft, Kimberly Belflower, and Sarah Ruhl introduce a new discourse on The Crucible's legacy. By using a feminist framework, these playwrights reclaim the narrative for the women oppressed by the trials and critique Miller's patriarchal influence on the perception of history. Perhaps in including new plays like these into the realm of media surrounding the witch trials, a fuller and more woman-centric perspective can honor one tragedy that shaped America's culture towards women.

Each day our eyes are opened more to the prejudice that has formed American history and continues to shape society today. Similar to the way the Salem witch trials have been rewritten from a white male perspective, other forms of racism, sexism, and xenophobia have been glossed over to glorify the white man. We as a nation have refused to open our eyes to the truth for centuries which has left us with an unchanging cycle of oppression. As recent events in society have shown us, we are finally beginning to listen and educate on the painful truth of our history. From there, we have a responsibility to educate ourselves and to create new work that elevates the voices of the marginalized. I believe the plays Abigail, John Proctor is the Villain, and Becky Nurse of Salem are examples of how understanding our true history can shape the way we see the world today. 


\section{CONCLUSION}

Arthur Miller's The Crucible has been influential in shaping the narrative surrounding the Salem witch trials and witch hunts in general in the United States. The real history of the witch trials, however, is far more complicated when considering gendered expectations, economic controls, and religious dictates. The grim period of history is responsible for the persecution of thousands of women based on the traditional view of women as inherently evil and on their ability to exercise independence. I argue that due largely to the popularity of The Crucible, this perception of women in the witch trials persists, as can be seen in the sexualized portrayals of Abigail and Tituba in recent popular culture such as the movie version of The Crucible (1996), the TV show Salem (2014-2017), and the anthology series American Horror Story: Coven (2011).

Miller's use of sexist tropes turned the witch trials into a man's fight for honor in the face of women's sexual temptation rather than a story about the suffering of oppressed women. He appropriates their struggles for his own personal and political gain and disguises this as allegory, despite relying on real names and events to tell his story. While Miller's attempt to expose McCarthyism's harsh practices is important, using and villainizing the lives of women to tell his story is a shameful misappropriation that center white men instead of oppressed women. The trend of appropriating the stories of Salem's women for man's personal gain is seen in the popular culture depictions discussed in chapter two. Film and television are infiltrated with depictions of the trials that make women into "others" or "femme fatales" who are punished for exerting their power and autonomy. This fulfills the need of the male gaze described by Laura Mulvey for men to see themselves as heroes and women as punishable and controllable. In these 
adaptations, we again see men appropriating real women's tragedies for their own gain.

The sexist way the history of the witch trials has been portrayed is coming to light, however, as female playwrights such as Sarah Tuft, Kimberly Belflower, and Sarah Ruhl have begun to produce work that calls out Miller's misrepresentation and creates a new standard of understanding of the trials. These authors also shed light on the connections of the trials to modern political issues in the United States, especially sexual assault allegations and the poor treatment of women by political leaders and their followers. Not only do these plays call out appropriation of the Salem witch trials, but they also expose the ways producing this play perpetuates and justifies sexism and abuse in contemporary society. Perhaps most importantly, these plays encourage women, through their plots and by example, to redeem the stories of Salem's women and call out sexism by creating new works which give the oppressed women a voice. There is still a glaring gap in this discourse, however, and that is found in the lack of discussion about Tituba and her marginalized position in Salem and in Miller's play. While these plays accomplish many goals in redeeming the real story of women from Miller's appropriation, they silence the voices of BIPOC women. Without the voices of these women, a feminist analysis is an incomplete and inaccurate depiction of The Crucible's sexism.

I am writing this thesis in the midst of great political turmoil and crises of morality in the United States. Writing a thesis about the Salem witch trials against a backdrop of a global pandemic, the loss of Black lives by police brutality, and the reversal of transgender healthcare rights has often left me feeling like my work is unimportant in the grand scheme of history. However, I have learned much from my work that I believe can be applied to the situations we face today. The first of these is that our history is often dictated by those in power, especially cis white men. Even when the true history is available to us, many choose to accept the stories that 
depict them as heroes rather than oppressors. In the Salem trials, men in power dominated the court and spurred on the trials by their greed for property and revenge. However, the story of popular knowledge has been warped to depict a heinous woman's lust and a foreign witch's devilry. Similarly, the history of the oppression of enslaved Black people and slain Indigenous people has been molded into a history of economic progress and manifest destiny. While the Salem witch trials may not be America's greatest tragedy, it is a tragedy that has been grossly misremembered. I argue that the dominance of writers like Miller contributes to this misinterpretation.

I do not argue that we do away with The Crucible. The play's historical and literary significance should not be discredited. However, I do argue that an examination of the consequences of Miller's work is necessary for its continued reproduction onstage and in classrooms. There is little other media that depicts the Salem witch trials in an accurate and alternative nature to Miller's white male gaze. I argue that new works about the witch trials of both nonfiction and fiction are needed to create a more comprehensive understanding of the time period. These works must be mindful not to reproduce the tropes Miller enforced like many works have but rather use creativity to remember the lives that were lost in the tragedy and to offer alternative understandings of the mystery of Salem.

My final argument concerns the normalization of the phrase, "witch hunt," in common conversation. A sexual assault scandal is not a witch hunt. An examination of a leader's crimes is not a witch hunt. An accusation of communism is not a witch hunt. A witch hunt is a historical tragedy that led to the execution of thousands of people. It is the oppression of female independence by patriarchal leaders. To use it to describe anything different is a disrespect and misunderstanding of history. Miller's use of the Salem witch trials as an allegory helped 
establish the precedent that this is an appropriate comparison to modern political turmoil. Unless thousands of women and girls are murdered, I refuse to accept "witch hunt" as a political term. In conclusion, I dedicate this thesis to the women of Salem. I dedicate it to those who were hanged for their refusal to confess: Bridget Bishop, Sarah Good, Elizabeth Howe, Susannah Martin, Sarah Wildes, Martha Carrier, Martha Corey, Mary Eastey, Mary Parker, Alice Parker, Ann Pudeator, and Margaret Scott. I dedicate it to the men who died defending them: George Burroughs, George Jacobs Sr., John Proctor, John Willard, Wilmot Redd, Samuel Wardell Scott Sr., and Giles Corey. I dedicate it to those who died in Salem's jail: Anne Foster, Sarah Osborne, Mercy, the infant daughter of Sarah Good, Lydia Dustin, and Roger Toothaker. I dedicate it to the countless young girls manipulated by a patriarchal society into convicting their friends and neighbors. I dedicate it to Dorcas Good, the five year old who went mad in prison. I dedicate it to Tituba, who sat forgotten in prison for years after the trials ended. I dedicate it to the women who have been forgotten by history. May we not forget what a society based in fear, religious radicalization, and oppression can create. 


\section{WORKS CITED}

Barstow, Anne Llewellyn. Witchcraze: a New History of the European Witch Hunts. Pandora, 1995.

Belflower, Kimberly. John Proctor is the Villain. 2019.

Bragga, Brannon and Adam Simon, creators. Salem. WGN America, 2014-2017.

Breslaw, Elaine G. Tituba, Reluctant Witch of Salem: Devilish Indians and Puritan Fantasies. New York University Press, 1996.

Carlson, Marvin. The Haunted Stage: The Theatre as Memory Machine . University of Michigan Press, 2003.

The Crucible. Directed by Nicholas Hytner, performances by Daniel Day-Lewis and Winona Ryder, Twentieth Century Fox, 1996.

DeRosa, Robin. The Making of Salem: the Witch Trials in History, Fiction and Tourism. McFarland, 2009.

Downey, Dara. “Tracing Tituba through American Horror Story: Coven.” European Journal of American Culture, vol. 38, no. 1, March 2019, pp. 15-27. EBSCOhost.

Falchuk, Brad and Ryan Murphy, creators. American Horror Story: Coven. FX, 2013-2014.

Fortier, Mark. Theory/Theatre: An Introduction. Routledge, 2016.

Garcia, Sandra E. "The Woman Who Created \#MeToo Long Before Hashtags.” The New York Times, The New York Times, 20 Oct. 2017.

Gentile, Katie. “Give a Woman an Inch, She'll Take a Penis.” Studies in Gender and Sexuality, vol. 19, no. 4, Routledge, Oct. 2018, pp. 241-45. 
Godbeer, Richard. “'Your Wife Will Be Your Biggest Accuser’: Reinforcing Codes of Manhood at New England Witch Trials." Early American Studies, vol. 15, no. 3, 2017, pp. 474-504.

Hansen, Chadwick. "The Metamorphosis of Tituba, or Why American Intellectuals Can't Tell an Indian Witch from a Negro.” The New England Quarterly, vol. 47, no. 1, The Colonial Society of Massachusetts and The New England Quarterly, Mar. 1974, pp. $3-12$.

Heinrich, Kramer and Jacob Sprenger. Malleus Maleficarum. Speyer, 1486.

Karlsen, Carol F. The Devil in the Shape of a Woman. W.W. Norton \& Company, 1998.

Kelly, Casey Ryan. "Donald J. Trump and the Rhetoric of Ressentiment." Quarterly Journal of Speech, vol. 106, no. 1, Routledge, Jan. 2020, pp. 2-24.

Littauer, Amanda H. Bad Girls : Young Women, Sex, and Rebellion Before the Sixties, University of North Carolina Press, 2015. ProQuest Ebook Central.

McGill, William J. "The Crucible of History: Arthur Miller's John Proctor.” The New England Quarterly, vol. 54, no. 2, The New England Quarterly, Inc, June 1981, pp. $258-64$.

Meslow, Scott. “The Sexist, Empowering History of the Femme Fatale.” The Week-All You Need to Know about Everything That Matters, The Week, 4 Mar. 2016.

Miller, Arthur. The Crucible. Viking Penguin Inc., 1953.

Mulvey, Laura. "Visual Pleasure and Narrative Cinema." Screen, 16, no. 4, 1975, pp. 6-18.

Norton, Mary Beth. In the Devil's Snare: the Salem Witchcraft Crisis of 1692. Vintage Books, 2003.

Pope, Victoria. "Myth Vs. Reality." no. 26, U.S. News and World Report, Dec. 1996, pp.19. 
Preston, VK. "Reproducing Witchcraft: Thou Shalt Not Perform a Witch to Live." TDR:

The Drama Review, vol. 62, no. 1, MIT Press, Mar. 2018, pp. 143-59.

Records of Salem Witchcraft, copied from the Original Documents. Roxbury, 1864.

Reis, Elizabeth. Damned Women: Sinners and Witches in Puritan New England.

Cornell University Press, 1999.

Ruhl, Sarah. Becky Nurse of Salem. 2019.

Salem Witch Trials. Directed by Joseph Sargent, CBS, 2002.

Savran, David. Communists, Cowboys, and Queers: the Politics of Masculinity in the Work of Arthur Miller and Tennessee Williams. University of Minnesota Press, 1992.

Schiff, Stacy. Witches, the: Salem, 1692. Orion Publishing Co, 2015.

Schlueter, June. Feminist Rereadings of Modern American Drama. Fairleigh Dickinson University Press, 1989.

“Season 1,” Unobscured from Aaron Mahnke, 2018.

Sollee Kristen J., and Coz Conover. Witches, Sluts, Feminists: Conjuring the Sex Positive. Three L Media., 2017.

Starkey, Marion L. The Devil in Massachusetts, a Modern Inquiry into the Salem Witch Trials. Doubleday, 1969.

Tuft, Sarah. Abigail. 2019.

Witches of Salem. Directed by Stephen Kemp, Travel Channel, 2019.

Yllmaz Demirkaya, Neslihan. "Scapegoating Non-Conforming Identities: Witchcraft Hysteria in Arthur Miller's The Crucible and Caryl Churchill's Vinegar Tom.” Tarih Kültür Ve Sanat Araştırmalari Dergisi, vol. 4, no. 2, Karabuk University, Dec. 2015, pp. $123-35$. 